\title{
ZYGOMATIC AIR CELL DEFECT - MAGNETIC RESONANCE IMAGING OF THE TEMPOROMANDIBULAR JOINT COMPARED WITH PANORAMIC RADIOGRAPHS
}

\author{
Dijana Zadravec ${ }^{1}$,Tomislav Badel${ }^{2}$, Mia Smoljan ${ }^{1}$, Samir $_{\text {Cimić }}^{2}$, \\ Nataša Katavić ${ }^{1}$ and Ivana Savić Pavičin ${ }^{3}$
}

\begin{abstract}
${ }^{1}$ Department of Diagnostic and Interventional Radiology, Sestre milosrdnice University Hospital Center, University of Zagreb, Zagreb, Croatia; ${ }^{2}$ Department of Removable Prosthodontics, School of Dental Medicine, University of Zagreb, Zagreb, Croatia; ${ }^{3}$ Department of Dental Anthropology, School of Dental Medicine, University of Zagreb, Zagreb, Croatia
\end{abstract}

\begin{abstract}
SUMMARY - The aim of the study was to analyze zygomatic air cell defect (ZACD) incidence using magnetic resonance imaging (MRI) and validity of panoramic radiograph as a comparative method of ZACD diagnostics. The connection between ZACD incidence, age, left/right temporomandibular joint (TMJ) and comorbidity with diagnosis of TMJ disorder was analyzed. Panoramic radiographs and MRIs of $140 \mathrm{TMJs}$ of 70 consecutive patients with previously confirmed TMJ diagnosis were compared in the study. A grading system (4-point scale from ' 0 ' for absence to ' 3 ' for most extended pneumatization) was used to determine low signal on MRIs as pneumatization of temporal bone. ZACD was diagnosed in 22 joints of 15 patients (incidence, 20.4\%), with seven patients having bilateral appearance. In the joints of nine patients, ZACD was identified as extensive according to the grading scale. The validity of ZACD findings on panoramic radiographs compared with MRI findings yielded 0.45 sensitivity and 0.98 specificity. There was no relation $(p>0.05)$ between comorbidity of ZACD and TMJ disorder, either by age or side of the body. More prevalent ZACD in our MRI analysis than in other researches based on panoramic radiographs could be explained by the expected superimposed osseous structures in the area of articular eminence.
\end{abstract}

Key words: Zygoma - diagnostic imaging; Magnetic Resonance Imaging; Radiography, Panoramic; Temporomandibular Joint Disorders; Temporal Bone; Croatia

\section{Introduction}

Zygomatic air cell defect (ZACD) or pneumatized articular eminence has been described as an extended area of squamous cells in the root of the zygomatic arch and in the temporal part of the temporomandibular joint $(\mathrm{TMJ})^{1}$. One of the morphological parameters of TMJ is measuring thickness of the roof of the gle-

Correspondence to: Tomislav Badel, DMD, Department of Removable Prosthodontics, School of Dental Medicine, University of Zagreb, Gundulićeva 5, HR-10000 Zagreb, Croatia

E-mail: badel@sfzg.hr

Received November 20, 2017, accepted February 15, 2018 noid fossa, which is, in radiologic analysis, indirectly related to ZACD presence ${ }^{2,3}$. Regarding TMJ traumatology, intracranial condylar dislocation can be increased during pneumatization of the temporal bone or during surgical procedure on $\mathrm{TMJ}^{4-6}$.

In general, ZACD rarely occurs with additional clinical symptomatology, and it was found accidentally on different radiological images of TMJ area, as described in clinical reports of patients with temporomandibular disorder (TMD) $)^{7}$. There are many studies on ZACD prevalence assessed on panoramic radiograph samples ${ }^{8-14}$. As in general skeletal radiology, TMJ transcranial diagnosis and multi-slice computed 
tomography (MSCT) were common tools for evaluation of ZACD, as well as cone beam computed tomography $(\mathrm{CBCT})^{15-18}$.

Magnetic resonance imaging (MRI) and CT are the gold standard of diagnostic properties for visualization of disc displacement (DD), osteoarthritis (OA) changes in the shape of the articular eminence, and subchondral tissues of TMJ ${ }^{19,20}$, and in differential diagnosis of orofacial pain related to otorhinolaryngology ${ }^{22,23}$. However, the air-filled area such as ZACD, studied by MRI, yields low signal intensity similar to osteoarthritic subchondral changes of $\mathrm{TMJ}^{9,24}$. The aim of the study was to analyze ZACD incidence using MRI and validity of panoramic radiograph as a comparative method of ZACD diagnostics. Also, the connection of ZACD incidence with age, gender, and left/right TMJ was investigated; since the study sample consisted of patients with the diagnosis of TMJ disorder, comorbidity of TMJ diagnosis and ZACD incidence was also taken into account.

\section{Materials and Methods}

At the Department of Removable Prosthodontics, 70 consecutive patients (median age 37.1, range 12-84; 79.7\% female) with clinical symptoms of TMJ disorder (painful joint with previously reported or present clicking, or/and limited mouth opening) were examined. Clinical diagnosis of DD and OA of TMJ by Diagnostic Criteria (DC) for TMD Axis I were confirmed by $\mathrm{MRI}^{25,26}$. None of the study patients had previous medical history of middle ear surgery, otitis media or any symptoms related to otology, or of maxillofacial fracture or anomalies. Since the analysis in this study was performed retrospectively, the follow-up showed no influence of other possible causes of low signal, such as fibrosis, osteosclerosis, bone islands, or tumors. Panoramic radiograph was used as a basic radiological document of orofacial pain diagnostics. $\mathrm{Pa}-$ tients were informed on the type and purpose of MRI diagnostics and gave their written consent for participation. The study was approved by the Ethics Committee.

Zygomatic air cell defect was studied using MRI and panoramic radiographs. According to Tyndall and Matteson ${ }^{1}, \mathrm{ZACD}$ is located posteriorly from the zygomaticotemporal suture in the zygomatic process of the temporal bone such as air-containing structures -

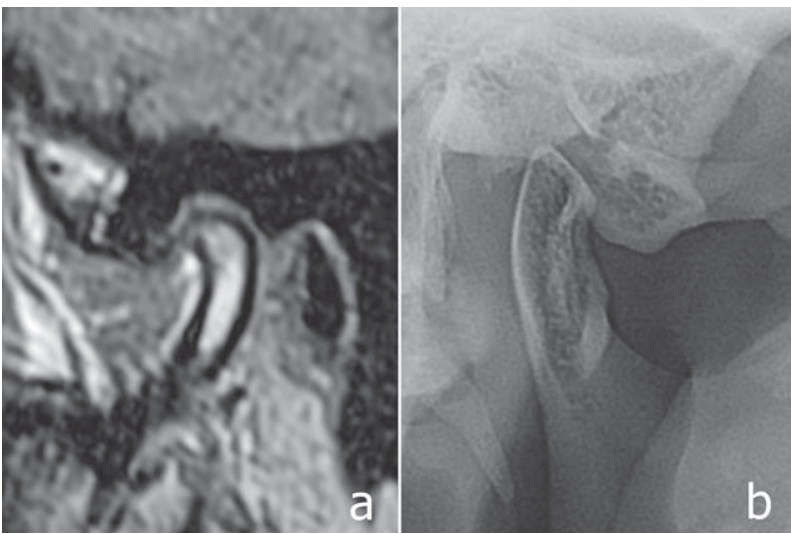

Fig. 1. Magnetic resonance image of the temporomandibular joint of a 62-year-old female with marked low signal area extending into the articular eminence (a); it corresponds to the finding seen on panoramic radiograph (b).

external auditory meatus and mastoid cells. The findings of ZACD by MRI were compared with TMJs on panoramic radiographs (Fig. 1). On comparison of MR images and panoramic radiographs as ZACD findings, a binary grading scale of ' 0 ' (no pneumatization present) and ' 1 ' (pneumatization present) was used for both methods.

\section{Magnetic resonance imaging}

Zygomatic air cell defect was examined at the Department of Diagnostic and Interventional Radiology, Sestre milosrdnice University Hospital Center, in the central parasagittal plane on MR images using a Magnetom Harmony 1.0 T unit and Magnetom Avanto $1.5 \mathrm{~T}$ unit (Siemens, Erlangen, Germany). The imaging sequences included using the Magnetom Harmony $\mathrm{T}_{1}$ weighted image (TR 450/TE 12 ) and $\mathrm{T}_{2}$ (TR 3000/TE 66) weighted image with matrix 256x192 and 160x160 field of view. Magnetom Avanto included $\mathrm{T}_{1}$-weighted (TR 450/TE 9.4) and $\mathrm{T}_{2}$-weighted (TR 770/TE 15) images with matrix 410x512 and 180x180 field of view. Proton density image (TR 2800/TE 90) had matrix 320x320 and 160x160 field of view.

In the parasagittal plane, seven slices of images were with 3-mm thickness in $\operatorname{size}^{27}$.

Marking the degree of ZACD spreading with a four-point system $(0 / 1 / 2 / 3)$ was carried out according to Wong and $\mathrm{Munk}^{24}$. Bone marrow signal was classi- 


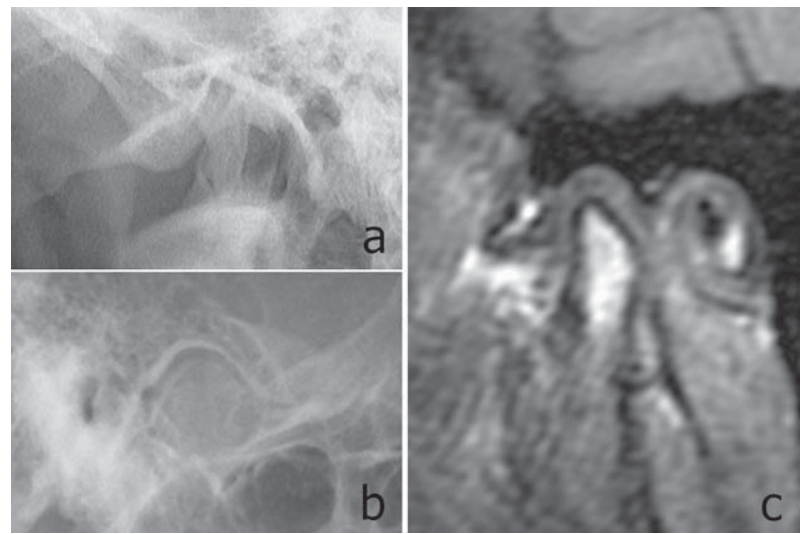

Fig. 2. Superposition of adjacent bone structures on panoramic radiograph (a) was shown in a 57-year-old female patient. Pneumatization visualized on temporomandibular joint transcranial radiography (b) and magnetic resonance image (c).

fied depending on fat/not fat marrow balance. The area of low signal within the temporal bone overlying the glenoid fossa was determined on MR images of TMJs.

Very low signal intensity on MR image is identical to cortical bone ${ }^{28}$. TMJ transcranial diagnostics modified according to Schüller (Fig. 2), MSCT or CBCT were produced by an external radiology specialist before initial dental or medical diagnostics prior to patient examination at the Department of Removable Prosthodontics due to TMJ symptoms. A low signal in the area of hyperostosis or pneumatization in the TMJ area was surveyed. In cases when the panoramic radiographs did not show pneumatization due to superimposed osseous structures, modified TMJ diagnostics by $\mathrm{x}$-ray diagnostics was used for differential diagnosis of $\mathrm{TMJ}$ in nine patients.

Zygomatic air cell defect was graded from 0 to 3 on the central parasagittal plane on MR images (Fig. 1). It was done as follows: the reference horizontal line on MR image was determined with points on the lower edge of external auditory meatus (point $\mathrm{M}$ ) and lowest edge of articular eminence (point A). This reference horizontal line was translated to the center of a circle inside the glenoid fossa (point C). From the center of the circle (point $\mathrm{C}$ ), a horizontal line was drawn anteriorly towards the articular eminence, as well as a vertical line which forms a right angle $\left(90^{\circ}\right)$ with the horizontal line. The anterior area of this right angle was divided into two equal halves (each of $\alpha=45^{\circ}$ ). The area

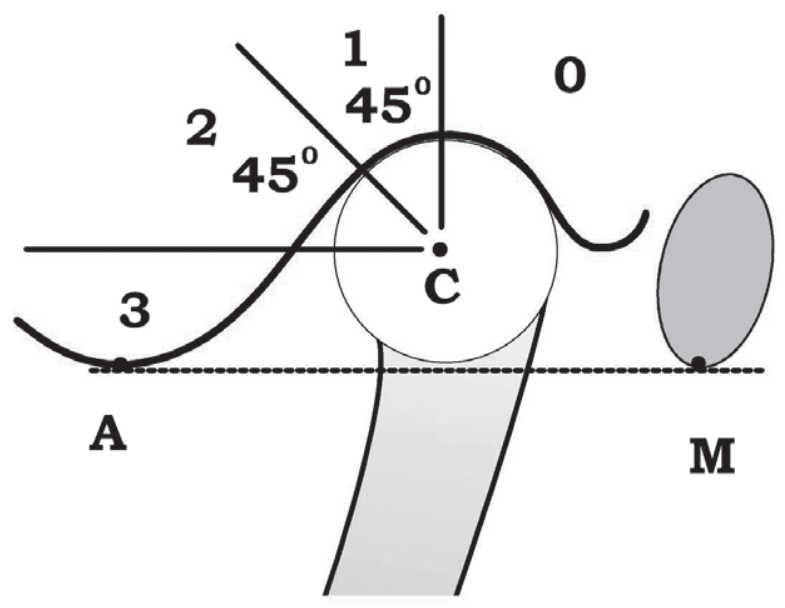

Fig. 3. The grading system used for the low signal area classification within the temporal bone overlying the glenoid fossa extending anteriorly into the articular eminence. From the arbitrary center of the glenoid fossa (C), a parallel line was drawn with the connecting line of the lowest edge of articular eminence $(A)$ and external on the lower edge of external auditory meatus $(M)$. A vertical line from point $C$ is the border since low signal does not go beyond this line from the posterior region and it is marked 'O'. The greatest spreading of low signal was marked '3'.

posterior to the vertical line was graded ' 0 ', which means that there was no ZACD because the low signal does not go beyond this vertical line anteriorly. The upper area within the right angle was graded ' 1 ', and the lower one was graded ' 2 '. Grading of ' 1 ' and ' 2 ' describes how far the low signal spreads anteriorly from the vertical line; the lowest grading degree of low signal area is ' 1 ', and a greater spreading is marked by ' 2 '. The most anteriorly widespread low signal area was marked as the articular eminence area inferiorly to the horizontal line and was graded ' 3 ' (Fig. 3). The radiographic appearance of ZACD was defined as radiolucency findings. ZACD was defined on panoramic radiographs as a single or numerous radiolucencies according to Tyndall and Matteson ${ }^{1}$.

\section{Statistical analysis}

Magnetic resonance imaging was used as the gold standard. Validity of panoramic radiographs as a comparative method in ZACD detection was tested using the specificity (the proportion of subjects without ZACD whose test was negative), sensitivity (the pro- 
portion of subjects with ZACD whose test was positive), positive predictive value (the proportion of test positive subjects who had ZACD), and negative predictive value (the proportion of test negative subjects who were without $\mathrm{ZACD})^{20}$.

Table 1. Validity of $Z A C D$ findings on panoramic radiographs compared with MRI findings

\begin{tabular}{|l|l|l|l|}
\hline & \multicolumn{2}{|c|}{ MRI } & $\mathrm{a} / \mathrm{a}+\mathrm{c}=0.45$ sensitivity \\
\hline PR & + & - & $\mathrm{d} / \mathrm{b}+\mathrm{d}=0.98$ specificity \\
\hline+ & 10 & 2 & $\mathrm{a} / \mathrm{a}+\mathrm{b}=0.83$ positive predictive value \\
\hline- & 12 & 116 & $\mathrm{~d} / \mathrm{c}+\mathrm{d}=0.91$ negative predictive value \\
\hline
\end{tabular}

$\mathrm{ZACD}$ = zygomatic air cell defect; $\mathrm{PR}$ = panoramic radiographs; $\mathrm{MRI}=$ magnetic resonance imaging
A radiologist (D.Z.) and a dentist (T.B.) experienced in TMJ diagnostics performed the analysis independently of each other. Additionally, the inter-examiner reliability was checked on MR images and panoramic radiographs of 25 patients.

Statistical data analysis was performed with the STATISTICA and SAS programs. Age difference between patients with and without ZACD was tested by $\chi^{2}$-test. The left and right TMJs of each person were presented as two separate entities in data analysis. Data were analyzed within three subgroups of joints formed with respect to the finding of ZACD, i.e. presence or absence of pneumatization between TMJs with or without anterior disc position ( $\chi^{2}$-test), differ-

Table 2. Gender ratio and zygomatic air cell defect appearance according to the side of the body in patient group

\begin{tabular}{|l|l|l|l|l|}
\hline Male $(\mathrm{n})$ & Female $(\mathrm{n})$ & Gender ratio $(\mathrm{F}: \mathrm{M})$ & Left/right $(\mathrm{n})$ & Unilateral/bilateral $(\mathrm{n})$ \\
\hline 6 & 9 & 0.67 & $13 / 9$ & $8 / 7$ \\
\hline
\end{tabular}

$\mathrm{n}=$ number of patients; number of joints; $\mathrm{F}=$ female; $\mathrm{M}=$ male

Table 3. Comparison of joints according to anterior disc position and $Z A C D$ for all joints in patients with $Z A C D$ in at least one joint

\begin{tabular}{|l|l|l|l|}
\hline \multirow{2}{*}{$\begin{array}{l}\text { Anterior disc } \\
\text { position }(\mathrm{n})\end{array}$} & \multicolumn{2}{|l|}{ Pneumatization $(\mathrm{n})$} & \multirow{2}{*}{ Total $(\mathrm{N})$} \\
\cline { 2 - 4 } & Yes & No & \\
\hline Yes & 14 & 5 & 19 \\
\hline No & 8 & 3 & 11 \\
\hline Total $(\mathrm{N})$ & 22 & 8 & 30 \\
\hline \multicolumn{2}{|l|}{ chi squared test $0.0033(\mathrm{df1})$ with $\mathrm{p}=0.955$} \\
\hline
\end{tabular}

$\mathrm{ZACD}=$ zygomatic air cell defect; $\mathrm{n}=$ number of joints

Table 4. Comparison of joints with ZACD by Wong and Munk ${ }^{24}$ grading system and presencelabsence of anterior disc position in the joint

\begin{tabular}{|l|l|l|l|l|}
\hline \multirow{2}{*}{$\begin{array}{l}\text { Joint } \\
\text { subgroup }\end{array}$} & \multicolumn{3}{|l|}{$\begin{array}{l}\text { Joints according to ZACD } \\
\text { grading system (n) }\end{array}$} & \multirow{2}{*}{ Total (N) } \\
\cline { 2 - 4 } & Grade 1 & Grade 2 & Grade 3 & \\
\hline 1 & 2 & 4 & 8 & 14 \\
\hline 2 & 3 & 4 & 1 & 8 \\
\hline Total (N) & 5 & 8 & 9 & 22 \\
\hline Fisher exact test=0.125 & \multicolumn{4}{|l}{} \\
\hline
\end{tabular}

ZACD = zygomatic air cell defect; subgroup $1=$ joints with anterior disc position and pneumatization; subgroup $2=$ joints without anterior disc position and with pneumatization; $\mathrm{n}=$ number of joints ent categories of pneumatization (1-3) using the grading system of Wong and $\mathrm{Munk}^{24}$ (Fisher exact test), and the same grading system (0-3) within the left and the right joints of patients with pneumatization in at least one joint (Fisher exact test). The level of statistically significant difference was set at $5 \%$.

\section{Results}

Using Cohen's kappa statistics, the measured interexaminer agreement was between 0.92 and 0.95 for MRIs and 0.75 and 0.86 for panoramic radiographs. The inter-examiner agreement for grading scale of ZACD on MRIs of the same 25 patients was 0.90 .

There was no significant age difference $\left(\chi^{2}\right.$-test= 1.4552; $\mathrm{df}=68 ; \mathrm{p}=0.1502)$ between patients with ZACD (median age 23) and those without ZACD (median age 38). Validity of ZACD findings on panoramic radiographs with MRI findings of the same patients was tested (Table 1). All TMJs had intact shape of articular eminence and glenoid fossa. High positive and negative predictive values were determined; however, there was a high specificity but lower sensitivity in comparison of panoramic radiographs with MRI of TMJ. The radiographically diagnosed incidence of ZACD for joints was $9.5 \%$, or 10 joints al- 
Table 5. Distribution of left-and right-side joints in 15 patients with $Z A C D$ (4-point grading system according to Wong and Munk ${ }^{24}$ )

\begin{tabular}{|c|c|c|c|c|c|}
\hline \multirow[b]{2}{*}{ Joint subgroup } & \multicolumn{4}{|c|}{ Joints according to ZACD grading system (n) } & \multirow[b]{2}{*}{ Total $(\mathrm{N})$} \\
\hline & $\begin{array}{l}\text { Grade } 0 \\
\text { (no ZACD) }\end{array}$ & Grade 1 & Grade 2 & $\begin{array}{l}\text { Grade } 3 \\
\text { (most widespread ZACD) }\end{array}$ & \\
\hline Left side (n) & 2 & 3 & 5 & 5 & 15 \\
\hline Right side (n) & 6 & 2 & 3 & 4 & 15 \\
\hline Total $(\mathrm{N})$ & 8 & 5 & 8 & 9 & 30 \\
\hline \multicolumn{6}{|c|}{ Fisher exact test $=0.482$} \\
\hline
\end{tabular}

$\mathrm{ZACD}=$ zygomatic air cell defect; $\mathrm{n}=$ number of joints

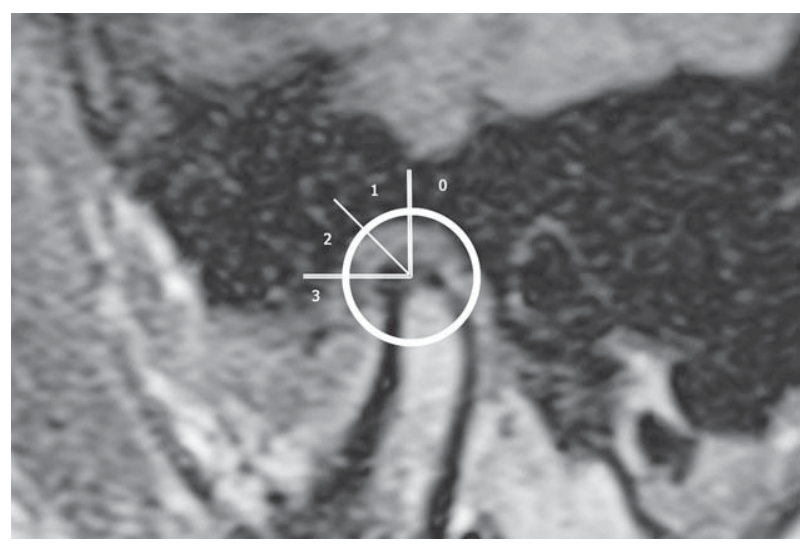

Fig. 4. Magnetic resonance image of the

temporomandibular joint in the central parasagittal plane of a 36-year-old male patient with anterior disc position. Low signal area within the temporal bone overlying the glenoid fossa extending into the articular eminence - the bighest degree of low signal wide spreading was grade '3' according to the grading system used in this study.

together. The incidence of ZACD by MRI diagnostics was $20.4 \%$, or 15 patients (mean age 30.7 , age range 17-63 years) of the general sample of 70 patients. The results of MRI findings (depending on patients or joints) are shown in Table 2.

There were no differences between joints $\left(\chi^{2}\right.$-test $=$ $0.0033 ; \mathrm{df}=1 ; \mathrm{p}=0.955)$ regarding the anterior disc position and ZACD occurrence in all 15 patients with ZACD (Table 3). ZACD was identified in $22 \mathrm{TMJ}$ in the patient subgroup: 5 joints were grade ' 1 ', 8 joints were grade ' 2 ', and 9 joints were grade ' 3 '. There were no differences in joints regarding anterior disc position ( $p=0.125)$ using the grading scale for ZACD on MRIs according to Wong and Munk ${ }^{23}$ (Table 4).

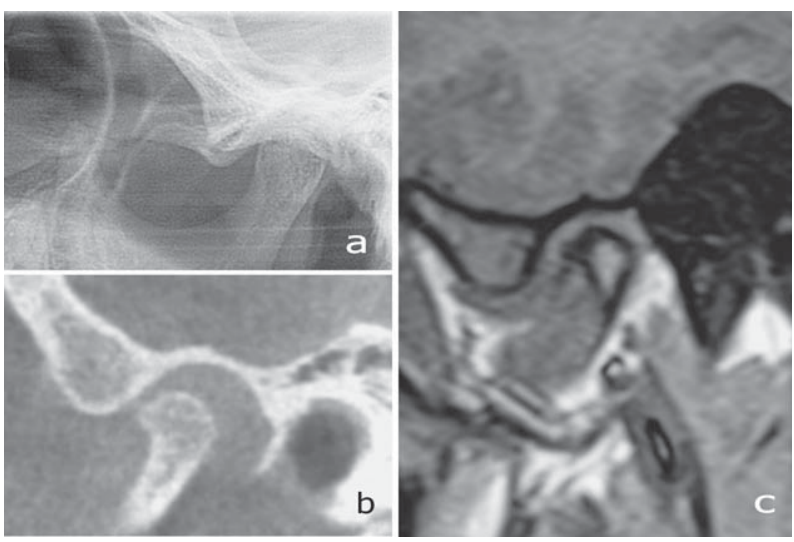

Fig. 5. False-positive findings of pneumatization can occur on panoramic radiograph (a). Pneumatization on cone-beam computed tomography (b) and magnetic resonance imaging (c) was missing in a 42-year-old female patient.

Independent comparison of the right- and left-side joints in 15 patients with ZACD (the ' 0 ' to ' 3 ' grading system) (Table 5) yielded no statistically significant difference (Fisher exact test $\mathrm{p}=0.482$ ).

\section{Discussion}

Tyndall and Matteson ${ }^{1}$ defined the following characteristics of ZACD: no clinical symptomatology, no radiological signs of expansive and/or destructive process in the bone, and the existence of various radiolucent formations not beyond the zygomaticotemporal suture. Research of zygomatic arch pneumatization has particular morphological, as well as clinical significance. It deals with the spreading of pneumatization process that impacts the osseous structures surround- 
ing the paranasal sinuses. The presence of ZACDs in the facial skeleton primarily changes the radiological image; and, in practice, it means the possible propagation of inflammatory processes after trauma/fracture of the temporal bone in the region overlying the glenoid fossa. Moreover, the presence of ZACDs should be considered prior to surgical interventions on the articular tuberculum of TMJ ${ }^{28}$.

The traumatological aspect of ZACD occurrence with respect to the morphological and clinical aspect of glenoid fossa thickness and articular eminence is relevant in cases of orofacial trauma, which could not only cause fractures but also condyle dislocation in middle cranial fossa ${ }^{4,6}$. Before performing a surgical procedure on the TMJ, the possibility of ZACD existence should be considered in order to avoid accidental opening and possible bacterial contamination ${ }^{6}$.

Thickness of the roof of the glenoid fossa can be indirectly related to ZACD. An autopsy study by Honda et al. ${ }^{2}$ showed that patients with OA of TMJ had thicker bone surfaces than those with healthy joints. It is expected that bone thickness will be greater on MR images because CT does not show soft cartilaginous tissues. However, as opposed to CT, on MR images ZACD will cause difficulties in differentiating between subchondral bone and air-containing cells. No-signal to low-signal intensity zone on MR images within the intact cortical temporal bone overlying the glenoid fossa cannot differentiate between hyperostosis and pneumatized bone ${ }^{3}$.

There is a series of studies which retrospectively evaluated panoramic radiographs, with a determined ZACD prevalence of $1.03 \%$ to $3.42 \%^{1,8-14}$. While the subjects of comparative radiology in our study were patients with TMJ disorder, recent studies of ZACD were more based on determining its prevalence by including larger groups of dental patients without previous symptomatology related to the stomatognathic system.

Groell and Fleischmann ${ }^{15}$ researched ZACD by means of CT in a sample of patients from maxillofacial surgery clinic and without TMJ symptomatology. They found various cases of ZACD expanding, i.e. air-containing cells were extended to the roof of glenoid fossa in $51 \%$ of patients, and $12 \%$ of patients had cells extended into the articular eminence. Miloglu et al. ${ }^{16}$ investigated orthodontic patients by CBCT with a ZACD prevalence of $6.47 \%$. In their representative study, Miloglu et al. ${ }^{17}$ included patients from oral radi- ology department and found ZACD using CBCT with a prevalence of $8 \%$. Wong and $\mathrm{Munk}^{24}$ retrospectively studied 12 patients with radiological findings related to ZACD. They promoted a four-point system $(0 / 1 / 2 / 3)$ on MRIs and found the following frequencies: $37.5 \% / 16.7 \% / 20.8 / 25 \%$ of 24 studied joints altogether. Only two TMJs had postoperative changes. In our study, there were no joints with similar patient history data.

Zygomatic air cell defect should certainly be considered as an additional radiological finding rather than a pathology requiring treatment or being connected to any form of TMJ disorder (OA, DD) $)^{29,30}$. Although ZACD prevalence is variable in the results of MSCT/CBCT/MRI researches ${ }^{15-18,24}$, this prevalence is higher than in numerous researches using panoramic radiographs ${ }^{8-11}$. Our research proved the instability of panoramic radiographs in comparison with MRI as a slice imaging technique. Discrepancies between ZACD prevalence rate in studies on panoramic radiographs and, for example, $\mathrm{CBCT}$ were also found by Miloglu et al. ${ }^{17}$. Using CBCT, İlgüy et al. ${ }^{18}$ found that $65.8 \%$ of individuals presented ZACD and $37.8 \%$ of patients had ZACD bilaterally. It was higher as compared with our study.

In conclusion, our study suffered from some limitations because it did not include general population of dental patients. However, the population of TMD patients who were eligible for MRI diagnostics was used in the study in order to compare MRI findings with panoramic radiographs, since MRI is not an appropriate method for epidemiological studies ${ }^{31-33}$. Low signal area in the temporal part of TMJ was determined as an effect of temporal bone pneumatization. Low sensitivity $(0.45$, the proportion of subjects with ZACD who tested positive) for ZACD findings on panoramic radiographs compared with findings on MR images of TMJ was determined in the study due to the superimposed osseous structures. The results of this research based on MRI indicated that ZACD occurred in $20.4 \%$ of patients with DD of TMJ, but it did not depend on patient age. ZACD is involved in the imaging of TMJ and related structures for differential diagnosis of TMJ disorders and treatment modalities of TMJ surgery.

\section{Acknowledgment}

We would like to thank Professor Ivan Krolo, a radiologist, for participating and providing patients for 
the study. The study was part of the scientific project entitled Orofacial Pain and Temporomandibular Joint Disorder - A Long-Term Follow-Up, supported by the University of Zagreb.

\section{References}

1. Tyndall DA, Matteson SR. Radiographic appearance and population distribution of the pneumatized articular eminence of the temporal bone. J Oral Maxillofac Surg. 1985;43:493-7. doi: 10.1016/S0278-2391(85)80026-4

2. Honda K, Larheim TA, Sano T, Hashimoto K, Shinoda K, Westesson PL. Thickening of the glenoid fossa in osteoarthritis of the temporomandibular joint. An autopsy study. Dentomaxillofac Radiol. 2001;30:10-3. doi: 10.1038/sj/dmfr/4600559

3. Kai Y, Matsumoto K, Ejima K, Araki M, Yonehara Y, Honda $\mathrm{K}$. Evaluation of the usefulness of magnetic resonance imaging in the assessment of the thickness of the roof of the glenoid fossa of the temporomandibular joint. Oral Surg Oral Med Oral Pathol Oral Radiol Endod. 2011;112:508-14. doi: 10.1016/j.tripleo.2011.05.013

4. Tsunoda A, Sumi T, Shirakura S, Kishimoto S, Akita K. Bony eminence on the middle cranial fossa corresponding to the temporomandibular joint. Clin Anat. 2007;20:512-5. doi: 10.1002/ca.20447

5. Benech A, Gallesio C, De Gioanni PP, Fasciolo A. Fracture of the glenoid fossa without condylar dislocation and with intact mandibular condyle. Report of a case. Minerva Stomatol. 1997;46:541-6.

6. de Almeida VL, Vitorino Nde S, Nascimento AL, da Silva Júnior DC, de Freitas PH. Stability of treatments for recurrent temporomandibular joint luxation: a systematic review. Int J Oral Maxillofac Surg. 2016;45:304-7.

doi: 10.1016/j.ijom.2015.10.022

7. Hasnaini M, Ng SY. Extensive temporal bone pneumatization: incidental finding in a patient with TMJ dysfunction. Dent Update. 2000;27:187-9.

8. Patil K, Mahima VG, Malleshi SN, Srikanth HS. Prevalence of zygomatic air cell defect in adults - a retrospective panoramic radiographic analysis. Eur J Radiol. 2012;81:957-9. doi: 10.1016/j.ejrad.2011.01.081

9. Hofmann T, Friedrich RE, Wedl JS, Schmelzle R. Pneumatisation des Jochbogens auf Panoramaschichtaufnahmen. Mund Kiefer Gesichts Chr. 2001;3:173-9. doi: 10.1007/s100060100289 (in German)

10. Orhan K, Delilbasi C, Orhan AI. Radiographic evaluation of pneumatized articular eminence in a group of Turkish children. Dentomaxillofac Radiol. 2006;35:365-70.

doi: $10.1259 / \mathrm{dmfr} / 77401728$

11. Orhan K, Oz U, Orhan AI, Ulker AE, Delilbasi C, Akcam O. Investigation of pneumatized articular eminence in orthodontic malocclusions. Orthod Craniofac Res. 2010;13:56-60. doi: 10.1111/j.1601-6343.2009.01476.x
12. Yavuz MS, Aras MH, Güngör H, Büyükkurt MC. Prevalence of the pneumatized articular eminence in the temporal bone. J Cranio Maxillofac Surg. 2009;37:137-9. doi: 10.1016/j.jcms.2009.01.006

13. Arora KS, Kaur P, Kaur K. ZACD: a retrograde panoramic analysis among Indian population with new system of classification. J Clin Diagn Res. 2016;10:ZC71-3. doi: 10.7860/JCDR/2016/15670.7147

14. Kishore M, Panat SR, Kishore A, Aggarwal A, Upadhyay N, Agarwal N. Prevalence of zygomatic air cell defect using orthopantomogram. J Clin Diagn Res. 2015;9:ZC09-11. doi: 10.7860/JCDR/2015/9045.6437

15. Groell R, Fleischmann B. The pneumatic spaces of the temporal bone: relationship to the temporomandibular joint. Dentomaxilofac Radiol.1999;28:69-72. doi: 10.1038/sj.dmfr.4600414

16. Miloglu O, Celikoglu M, Yildirim E, Yilmaz AB, Demirtas O. Pneumatized articular eminence in a cohort of orthodontic patients with different sagittal skeletal anomalies: a retrospective cone beam computed tomography study. Oral Radiol. 2010; 26:82-8. doi: 10.1007/s11282-010-0045-6

17. Miloglu O, Yilmaz AB, Yildirim E, Akgul HM. Pneumatization of the articular eminence on cone beam computed tomography: prevalence, characteristics and a review of the literature. Dentomaxillofac Radiol. 2011;40:110-4. doi: $10.1259 / \mathrm{dmfr} / 75842018$

18. İlgüy M, Dölekoğlu S, Fişekçioğlu E, Ersan N, İlgüy D. Evaluation of pneumatization in the articular eminence and roof of the glenoid fossa with cone-beam computed tomography. Balkan Med J.2015;32:64-8. doi:10.5152/balkanmedj.2015.15193

19. Park JW, Song HH, Roh HS, Kim YK, Lee JY. Correlation between clinical diagnosis based on RDC/TMD and MRI findings of TMJ internal derangement. Int J Oral Maxillofac Surg. 2012;41:103-8. doi: 10.1016/j.ijom.2011.09.010

20. Jerolimov V. Temporomandibular disorders and orofacial pain. Rad 504 Medical Sciences 2009;33:53-77.

21. Caruso S, Storti E, Nota A, Ehsani S, Gatto R. Temporomandibular joint anatomy assessed by CBCT images. Biomed Res Int. 2017;2017:2916953. doi: 10.1155/2017/2916953

22. Badel T, Čimić S, Munitić M, Zadravec D, Bašić Kes V, Kraljević Šimunković S. Clinical view of the temporomandibular joint disorder. Acta Clin Croat. 2014;53:462-70.

23. Badel T, Pandurić J, Marotti M, Kocijan Lovko S. Temporomandibular joint disorder in an otalgia patient. Acta Stomatol Croat. 2006;40:175-81.

24. Wong K, Munk PL. Magnetic resonance imaging of the temporomandibular joint: diagnostic difficulty caused by extensive pneumatization of the mastoid air cells. Skeletal Radiol. 1999;28:577-80. doi: 10.1007/s002560050622

25. Laškarin M, Badel T, Kern J, Savić Pavičin I, Zadravec D. Metric evaluation of partially displaced temporomandibular joint disc. Acta Clin Croat. 2014;53:310-8.

26. Badel T, Marotti M, Kraljević Šimunković S, Keros J, Kern J, Krolo I. Radiological characteristics of osteoarthritis of tem- 
poromandibular joint without disc displacement. Period Biol. 2009;111:289-92.

27. Badel T, Laškarin M, Čimić S, Zadravec D. Partial articular disc displacement in patients with TMJ disorder. Acta Stomatol Croat. 2015;49:174. [Abstract].

28. Vande Berg BC, Malghem J, Lecouvet FE, Maldague B. Classification and detection of bone marrow lesions with magnetic resonance imaging. Skeletal Radiol. 1998;27:529-45. doi: 10.1007/s002560050434

29. Badel T, Marotti M, Savić Pavičin I, Dulčić N, Zadravec D, Kern J. Temporomandibular disorders - validity of clinical diagnostics compared to magnetic resonance imaging. Period Biol. 2011;113:207-12.

30. Badel T, Savić Pavičin I, Čimić S, Zadravec D. Diagnostics and management of temporomandibular joint disorder - a reported case with a review of literature. J Dent Probl Solut. 2016;3: 018-023. doi: 10.17352/2394-8418.000027

31. Štoković N, Trkulja V, Dumić-Čule I, Čuković-Bagić I, Lauc T, Vukičević S, Grgurević L. Sphenoid sinus types, dimensions and relationship with surrounding structures. Ann Anat. 2016;203:69-76. doi: 10.1016/j.aanat.2015.02.013

32. Čimić S, Badel T, Šimunković SK, Pavičin IS, Ćatić A. Centric slide in different Angle's classes of occlusion. Ann Anat. 2016;203:47-51.

doi: 10.1016/j.aanat.2015.09.001

33. Jeyaraj P, Chakranarayan A. A conservative surgical approach in the management of longstanding chronic protracted temporomandibular joint dislocation: a case report and review of literature. J Maxillofac Oral Surg. 2016 Jul;15(Suppl 2):361-70. doi: $10.1007 / s 12663-016-0900-z$

Sažetak

\section{PNEUMATIZACIJA JAGODIČNE KOSTI - USPOREDBA MAGNETSKE REZONANCIJE TEMPOROMANDIBULARNOG ZGLOBA S ORTOPANTOMOGRAMOM}

\section{Zadravec, T. Badel, M. Smoljan, S. Čimić, N. Katavić i I. Savić Pavičin}

Svrha istraživanja bila je analizirati incidenciju pneumatizacije jagodične kosti uporabom magnetske rezonancije kao i validnost ortopantomograma kao komparativne metode u dijagnostici pneumatizacije. Analizirana je povezanost između incidencije pneumatizacije jagodične kosti, dobi, odnosa lijevog/desnog temporomandibularnog zgloba (TMZ) kao i komorbiditet s dijagnozama poremećaja TMZ-a. U ovoj studiji uspoređeni su ortopantomogrami s magnetskom rezonancijom TMZ-a kod 70 uzastopnih bolesnika s prethodno potvrđenim dijagnozama poremećaja TMZ-a. Primijenjen je sustav stupnjevanja (ljestvica s 4 kategorije: od '0' kao izostanak do ' 3 ' kao najviše ekstendirana pneumatizacija) za utvrđivanje slabog signala magnetske rezonancije kao pneumatizacije temporalne kosti. Pneumatizacija jagodične kosti dijagnosticirana je u 22 zgloba 15 pacijenata (incidencija 20,4\%) te bilateralna pojava kod 7 pacijenata. Kod 9 pacijenata utvrđena je ekstenzivna pneumatizacija jagodične kosti po ljestvici stupnjevanja. Validnost nalaza pneumatizacije jagodične kosti na ortopantomogramima u usporedbi s nalazom magnetske rezonancije pokazala je osjetljivost 0,45 i specifičnost 0,98 . Nije bilo korelacije $(p>0,05)$ između komorbiditeta pneumatizacije jagodične kosti i poremećaja TMZ-a, niti po dobi niti po strani tijela. U našoj analizi magnetskom rezonancijom veća učestalost pneumatizacije jagodične kosti nego u ostalim istraživanjima zasnovanim na ortopantomogramu objašnjava se superponiranjem koštanih struktura u području zglobne kvržice.

Ključne riječi: jagodična kost - dijagnosticko snimanje; magnetska rezonancija - snimanje; radiografija, panoramska; temporomandibularni zglob, poreméaji; temporalna kost; Hrvatska 